\title{
THE IMPACT OF COVID-19 ON LABOUR MARKET IN NORTH MACEDONIA
}

\author{
Merita Zulfiu Alili \\ South East European University \\ m.zulfiu@seeu.edu.mk
}

\begin{abstract}
An initial assessment of the impact of COVID-19 on the North Macedonian labour market is widely anticipated that will be severe, pushing thousands of people into unemployment, underemployment and working poverty. This paper aims to assess the impact of the COVID19 outbreak on labour market by analysing the most affected sectors and government measured aimed to prevent job losses. Many small and medium businesses have already closed their operations or decreased the number of employees. The most affected industries due to the outbreak of the COVID-19 are the tourism industry and export-oriented industries, including the textile sector. To mitigate the consequences of COVID-19 the Government of North Macedonia has adopted measures for support of the firms which aim to keep jobs, maintain social stability, and help the citizens affected by the crisis. Specific local labour market characteristics should be considered when specifying eligibility criteria and undertaking crisis response measures.
\end{abstract}

Keywords: COVID-19, labour market, job losses, response measures

JEL classification: $J 21$

\section{INTRODUCTION}

While it is not yet possible to fully predict the economic downturn from the coronavirus pandemic and the measures currently being taken to combat it, it is becoming increasingly clear that the effects on the world economy will be severe, probably far more severe than those we have seen during of the financial crisis from 2007 to 2009. As a result of COVID-19 25 million jobs are expected to be lost worldwide, says ILO, which will depend on how strongly economic activity is affected. If this crisis it has damaged developed economies, it is expected that developing and transition economies to be severely damaged.

In the first days of the pandemic, state institutions in North Macedonia acted with good speed and a lot of professionalism, closing schools and public places, but this also began to affect businesses and unemployment, and helped the multi-year economic crisis in the country to deepen. The economy of North Macedonia has been damaged like many other world economies, but it is difficult to say how much damage has been done. It is estimated that three-quarters of employees and companies in North Macedonia are hit by the economic crisis caused by the spread of COVID-19 (Finance Think, 2020). The situation among the selfemployed and micro-businesses is a story and very critical. The many methods that employers have used during the crisis and because of adapting to the new and very difficult situation are the reduction of salaries and the prohibition of any kind of additional salaries. Unemployed people have almost lost hope of being employed in this difficult period, seeing that even employees are at risk of their jobs. While the best way to overcome the crisis is to reduce daily and monthly expenses, which seems very impossible because every family and every person has their own personal needs that must be met (Finance Think, 2020).

The recession in North Macedonia and in all Western Balkan countries in 2020 will be driven by a significant drop in both domestic and foreign demand because of pandemic crisis. Travel restrictions and social distancing measures have particularly affected tourism and services, the 
latter accounting for around $50 \%$ of total employment in fivel countries in the region including North Macedonia (World Bank, 2020). According to tourism association about 70,000 jobs are threatened in this sector in North Macedonia (Gjorgjioska, 2020). IMF estimates the unemployment rate of $17.3 \%$ in 2019 to increase to $20.4 \%$ in 2020 and decrease slightly to $19 \%$ in 2021. Revenues in March 2020 have declined from $40 \%$ to $65 \%$ as compared to 2019. A sharp decline is also observed in tax revenues by $11 \%$ in March 2020 compared to previous year. This is a result of $17 \%$ drop in VAT revenues, $11 \%$ in excise revenues and $11 \%$ in profit tax revenues (OECD, 2020).

In this paper the investigation focuses on the impact of the COVID-19 outbreak on labour market by analysing the most affected sectors and government measured aimed to prevent job losses. The analysis is organised as followed. Initially, losses of most affected sectors are analysed focusing on labour. Section 3 presents a review of Government measures of other states affected my COVID-19 and comparison with the measures undertaken by the Government of the Republic of North Macedonia. The final section summarises the key findings and explores their implications for policy recommendations.

\section{MOST AFFECTED SECTORS BY COVID-19 IN NORTH MACEDONIA}

The coronavirus pandemic is causing a notable slowdown in the economy, which is dependent on trade and investments from the EU (e.g. almost $50 \%$ of exports are directed to Germany) (OECD, 2020). Nine out of ten of its biggest export markets are countries in which the virus was rapidly spreading and which had also imposed high restrictions: Germany, Greece, Britain, Italy, China, Serbia, Bulgaria, Romania and Belgium (Gjorgjioska, 2020). As a result, exports of both services and goods are projected to go down-total exports growth in 2020 would drop by $-0.2 \%$ in North Macedonia. In Q2, manufacturing, construction, tourism, trade and real estate, may contract by $11.5 \%$ (World Bank, 2020). Problems are also faced with imports caused by the high dependence on materials such as food, livestock, basic materials needed for industrial production processes which are usually imported also from the worst-hit markets in Europe (Gjorgjioska, 2020).

Within the domestic markets SMEs, manufacturing and tourism sectors are among the most affected. In recent years on average $40 \%$ of exports and $60 \%$ of imports have been conducted through small and medium enterprises, which have been the worst hit in the crisis (Gjorgjioska, 2020). Manufacturing output declined by 2\%. A survey conducted by Finance Think (2020) asked if the company where they work was damaged by the current crisis, a large number said it was the result of state measures to shut down certain companies (for example, small companies operating in shopping malls) or because their sales have dropped significantly, $43.1 \%$ and $41.5 \%$. It is obvious that the percentage of companies that have had problems placing their products most often refers to export-oriented companies, whose orders were cancelled by customers (including from mother companies) abroad and / or who were affected by transport problems. The aggravated functioning of companies because significant number of workers went on sick leave or childcare for children up to 10 years of age was not identified as significant factor of economic crisis that hit the company, though this answer may be biased because it was given by employee perspective (Finance Think, 2020).

In addition, we briefly review the situation and vulnerabilities of regional labour markets. In countries where the labour market is characterised with informal and temporary employment and with disproportionate self-employment, it is more likely for these countries to face greater job losses which will cause significant difficulties especially if the networks of social protection are inadequate. Until the end of 2019, the employment rate in the Western Balkans increased to $44.3 \%$ (the employment rate in 2018 was $42.7 \%$ and in 2012 it was $36.9 \%$ ).

\footnotetext{
${ }^{1}$ Albania, Bosnia and Herzegovina, Kosovo, North Macedonia, Serbia.
} 
However, most of the jobs were in the low paid labour-intensive sectors in manufacturing and services. Low employment rate and high unemployment rate had significantly negative impact on inclusive growth in the Western Balkans (World Bank, 2020). A lot of jobs are temporary or informal. As a result of COVID-19 these jobs became very vulnerable reversing the employment growth from recent years. Most of these workers may not have access to social protection networks. As shown in Table 1 these problems are particularly acute in Kosovo (low employment, a large part of it temporary), Bosnia and Herzegovina (low employment rate and high rate of informal sector) and in Albania (high self-employment and informal employment) (World Bank, 2020).

Table 1. Labour market indicators in Western Balkan Countries, 2019

\begin{tabular}{|l|c|c|c|c|c|c|}
\hline & Albania & $\begin{array}{c}\text { Bosnia and } \\
\text { Herzegovina }\end{array}$ & Kosovo & Montenegro & $\begin{array}{c}\text { North } \\
\text { Macedonia }\end{array}$ & Serbia \\
\hline $\begin{array}{l}\text { Self-employed } \\
(\% \quad \text { of total } \\
\text { employment) }\end{array}$ & 34.7 & 17.6 & 21.3 & 19.4 & 14.3 & 22.4 \\
\hline $\begin{array}{l}\text { Employees on } \\
\text { temporary } \\
\text { contracts (\% of } \\
\text { total } \\
\text { employment) }\end{array}$ & 9.7 & 17.5 & 79.5 & 34.6 & 16.1 & 22.6 \\
\hline $\begin{array}{l}\text { Informal } \\
\text { employment (\% } \\
\text { of total } \\
\text { employment) }\end{array}$ & 61 & 29.5 & & 19.9 & & 19.8 \\
\hline $\begin{array}{l}\text { Employment rate } \\
\text { (\% of population } \\
\text { over 15 years) }\end{array}$ & 52 & 34.3 & 25.4 & 48.1 & 44.9 & 48.6 \\
\hline
\end{tabular}

(Source: World Bank (2020). The Economic and Social Impact of COVID-19, Western Balkans Regular Economic Report, no.17.)

The job crisis will disproportionately affect certain groups, which could increase inequality. These include people in less protected and low-paid jobs, especially young and older workers as well as women and migrants. Migrants are a vulnerable group due to a lack of social protection and rights, and women are usually more present in low-paid jobs and in affected sectors (SSM, 2020). Young people face higher probability in losing their jobs in times of crisis because they are employed in jobs with lower wages and everything is unsafe for them. On the other hand, workers in IT sector are less affected by the crisis, are more flexible and working from home in this time of crisis. One in four people who have lost their jobs during the coronavirus pandemic in the country is under 29 years old. This was announced by the employment agency. According to their data, from March 11 to May 31 of this year, almost 12,000 people have lost their jobs, or approximately 3,300 of them are under 29 years old. This does not include those who work in the black market. ILO tracks declines in working hours resulting from both lay-offs and other temporary reductions in working hours. Application of this ration would imply a loss of approximately 85,550 full-time equivalent jobs (assuming a 40-hour working week) during quarter 2 in North Macedonia ( ILO and European Bank, 2020). 


\section{GOVERNMENT MEASURES}

The new economic crisis caused by the pandemic also did not leave aside the most developed countries of the world which having a larger number of private companies saw a huge decline and some micro-businesses were also closed. In response to the crisis, central banks in many countries, including the United Kingdom, lowered interest rates. This seems, in theory, to make borrowing cheaper and to encourage spending to boost the economy. Some world markets have managed the situation very well and have recovered from the aid received from the state. However, many analyses have predicted that these benefits from the state may be very unstable, and if a second and more powerful wave of pandemics comes, the market will find it very difficult to overcome the crisis even if it accepts the benefits from the state. Unemployment has also emerged as a very important thing even in the most powerful states. In the United States, for example, the unemployment rate has increased from $3.7 \%$ to $10.4 \%$, according to the International Monetary Fund (IMF), signalling the end of a decade of expansion for one of the world's largest economies. Millions of people there have come to the aid of the state and can maintain their existence only through those aids, more precisely, they are workers in sectors such as tourism, and some jobs have even been closed. However, the data vary between countries. France, Germany, and Italy provide figures on applications, for example, while the United Kingdom counts workers currently enrolled in the scheme. However, in some cases improvements have been seen, such as China and France having employment increases in recent months. Most importantly, many experts think that there may be a longer-term damage to the employee process and many jobs will not be created for a long time (BBC, 2020).

Most of the measures introduced in the Western Balkans so far focus on supporting the cash flows of businesses to reduce bankruptcies and thus protect jobs in the next few months until COVID-19 containment restrictions can be lifted (World Bank, 2020). The crisis response measures undertaken in the Western Balkans are so far align with the policy responses of most EU countries, but initial conditions in these countries are different and therefore also the policy trade-offs. These measures are primarily dedicated to formal firms and workers. For example, wage subsidies as in most EU countries in North Macedonia and Serbia are conditional on keeping registered employees. However, given that Western Balkans labour markets have low employment rates, self-employment, part-time, and informal firms and workers are more common, they may receive little support from governments in this case (World Bank, 2020).

On the other hand, the Government of the Republic of North Macedonia has also taken measures to help the economy. Starting in April 2020 the Government has implemented a three-month fiscal package ( $0.2 \%$ of GDP) to help firms to address the liquidity problems and protect jobs, targeted to sectors such as transport, hotel, and restaurants. In addition, the Government introduced a tax deferral system for VAT returns. In May the Government also introduced a tax deferral system, for excise duties for selected excise goods (mainly auxiliary medicines and disinfectants) (OECD, 2020). The Government has introduced a support programme on salaries by subsidising contributions to employees of companies in tourism, transport and catering sectors as well as other affected companies, for the months of April, May and June of 2020. If the company does not reduce the number of employees below the number from February 2020 it is also entitled for subsidise of employee contributions up to $50 \%$ of the average salary paid in 2019 (OECD, 2020). Other measures include credit support mainly aimed at promoting more favourable credit standards for companies affected by the COVID-19 crisis. In addition, reduction of the instalment and reprogramming of loans to financial companies and leasing companies; state guarantee for commercial loans and customs debt; support for the development of domestic start-up products and services; and addition support to tourism, textile and agro-food sector should help firms to overcome losses 
caused by COVID-19. Table 2 summarises short-term measures to mitigate the social and economic impact of COVID-19 in North Macedonia.

Table 2. Short-term Measures to Mitigate the Social and Economic Impact of COVID-19 in North Macedonia

\begin{tabular}{|c|c|c|c|}
\hline Country & Fiscal and Trade-related & Monetary and financial & Social Assistance \\
\hline $\begin{array}{l}\text { North } \\
\text { Macedonia }\end{array}$ & $\begin{array}{l}\text { Reduction of interest } \\
\text { and parafiscal charges } \\
\text { Temporary suspension } \\
\text { of PIT payments and } \\
\text { advance CIT } \\
\text { payments for } \\
\text { taxpayers who earn } \\
\text { income from self- } \\
\text { employment for the } \\
\text { months of March, } \\
\text { April and May 2020, } \\
\text { specifically in } \\
\text { catering, tourism, and } \\
\text { transport but also } \\
\text { applicable to other } \\
\text { sectors affected } \\
\text { Reduced interest rates } \\
\text { on tax arrears and } \\
\text { overpayments } \\
\text { Support to protect } \\
\text { jobs: direct cash } \\
\text { transfers to companies } \\
\text { that fulfil certain } \\
\text { criteria, to be used to } \\
\text { pay salaries and keep } \\
\text { workers employed } \\
\text { Temporary prohibition } \\
\text { on initiating } \\
\text { bankruptcy } \\
\text { proceedings } \\
\text { Salary reduction for } \\
\text { all elected and } \\
\text { appointed officials, } \\
\text { who will be paid the } \\
\text { minimum wage } \\
\text { Abolition of } \\
\text { remuneration for } \\
\text { members of executive } \\
\text { and supervisory } \\
\text { boards and } \\
\text { committees during } \\
\text { crisis. }\end{array}$ & $\begin{array}{l}\text { Direct financial } \\
\text { support for eligible } \\
\text { MSMEs that become } \\
\text { insolvent due to the } \\
\text { coronavirus crisis } \\
\text { Reduction of the base } \\
\text { Central Bank (CB) } \\
\text { interest rate from } 2 \text { to } \\
\text { a historic low of } 1.75 \\
\text { percent } \\
\text { Temporary changes } \\
\text { to loan terms } \\
\text { Reduction of the } \\
\text { penalty interest rates } \\
\text { for companies and } \\
\text { individuals } \\
\text { Reintroduction of the } \\
\text { non-standard reserve } \\
\text { requirements } \\
\text { Extended deadline for } \\
\text { banks to submit their } \\
\text { first internal } \\
\text { Liquidity Assessment } \\
\text { Reports } \\
\text { Abolition of fees for } \\
\text { withdrawing and } \\
\text { returning cash to the } \\
\text { CB central vault } \\
\text { Temporary freeze of } \\
\text { NPL reclassification } \\
\text { Zero interest rate } \\
\text { loans for SMEs } \\
\text { provided through the } \\
\text { Development Bank. }\end{array}$ & $\begin{array}{l}\text { Subsidies for social } \\
\text { contributions to } \\
\text { eligible companies } \\
\text { in tourism, } \\
\text { transport, catering, } \\
\text { and other affected } \\
\text { companies for } \\
\text { April, May, and } \\
\text { June. Up to } 50 \\
\text { percent of the } \\
\text { contributions of the } \\
\text { average salary paid } \\
\text { in } 2019 . \\
\text { Exemption from } \\
\text { rent for the } \\
\text { beneficiaries of } \\
\text { social housing } \\
\text { Cash benefit for } \\
\text { citizens who have } \\
\text { lost their jobs } \\
\text { (50\%of the average } \\
\text { employee's salary) } \\
\text { Temporary } \\
\text { relaxation of the } \\
\text { criteria for applying } \\
\text { for social } \\
\text { assistance. }\end{array}$ \\
\hline
\end{tabular}

(Source: World Bank, 2020. The Economic and Social Impact of COVID-19. Western Balkans Regular Economic Report, no.17.) 
In September 2020, the Government introduced the fourth package of economic measures worth 350 million euros which is a continuation of the previous three packages and aims at supporting the most affected sectors and categories of citizens. The fourth package of economic measures includes support for payment of salaries for the last quarter of the year, payment cards for certain categories of citizens who need help the most, grants for the most affected sectors, reduction or abolition of parafiscal duties, increase of the grace period for interest-free loans from COVID-19 and additional postponement of loan repayment by companies. The fourth package of economic measures is evaluated by the members of the Economic and Social Council to be quite extensive and it is expected to have a positive impact on the labour market by preserving jobs.

\section{CONCLUSION}

The crisis has already turned into a shock to the economy and labour markets, affecting it not only on supply (production of goods and services), but also on demand side (consumption and investment). The COVID-19 crisis has already reduced some of the benefits for the workforce in the Western Balkans. The decline in employment in the Western Balkans is already obvious. Companies quickly began to take defensive measures: changes in working hours, temporary reductions in working hours, forced leave, unpaid leave, and even layoffs or forced closures to cope with the reduction in operations. Effective communication, social dialogue and clear government commitments are critical to limiting job losses.

The recovery in investment and activity in sectors such as services, tourism, construction, energy, will support job creation in 2021. The acceptance of North Macedonia in NATO and the invitation of EU Council to open negotiations for joining the EU should also help economic recovery. However if the pandemic crisis is prolonged combined with a deeper recession in EU could make the unfolding economic crisis difficult to handle in North Macedonia and on other Balkan countries (World Bank, 2020). It would further increase economic uncertainty and economic and social costs. Economic development in North Macedonia and in the region will depend on acceleration of structural reforms to boost productivity by reinforcing the state institutions that protect the rule of law; safeguarding private sector competition; addressing skills mismatches; and improving public services to boost human capital (World Bank, 2020). In addition, specific local labour market characteristics should be considered when specifying eligibility criteria and undertaking crisis response measures.

The deteriorating impact of COVID-19 on the labour market leaves policy makers to confront major policy challenges. They need to find the right balance and sequence of health and economic and social policy interventions to produce optimal sustainable labour market outcomes (ILO, 2020). Women, young people and informal workers are among those who have suffered the most consequences and hence, explicit attention should be paid to improving the position of the most disadvantaged and voulnerable groups. Governments need to work together with employers and workers in shaping effective, balanced and acceptable policy responses at the sectoral and national level (ILO, 2020). Responding to COVID-19 pandemic will require economic structural changes necessary to ensure adequate safety protection and workers to gain more power. The policy actions need to include lasting structural reforms to ensure that in the time of crisis, small businesses can access financial support easily and quickly in order to manage the crisis effectively and efficiently. 


\section{REFERENCES}

ILO and European Bank. (2020). "COVID-19 and the World of Work", Rapid Assessment of the Employment Impacts and Policy Responses, North Macedonia. Geneva: International Labour Organization.

BBC. (2020, June 30). Coronavirus: A visual guide to the economic impact. Retrieved from BBC News: https://www.bbc.com/news/business-51706225

Finance Think. (2020). Economic Effects of Corona Crisis. Skopje: Finance Think.

Gjorgjioska, A. (2020). North Macedonia economy briefing:The economic contagion of COVID 19 - early shocks and measures. Budapest: China-CEE Institute.

ILO. (2020). ILO Monitor:COVID-19 and the world of work. Fifth edition. Updated estimates and analysis. International Labour Organisation.

OECD. (2020). The COVID-19 Crisis in North Macedonia. OECD.

SSM. (2020, July 10). ALMOST 25 MILLION JOBS COULD BE LOST WORLDWIDE AS A RESULT OF COVID-19, SAYS ILO. Retrieved from Federation of Trade Unions of Macedonia: http://www.ssm.org.mk/en/almost-25-million-jobs-could-be-lost-worldwideresult-covid-19-says-ilo

World Bank. (2020, April 29). Recession Looms for Western Balkans as Countries Respond to COVID-19. Retrieved from The World Bank, IBRD, IDA:

https:/www.worldbank.org/en/news/press-release/2020/04/29/recession-looms-for-westernbalkans-as-countries-respond-to-covid-19

World Bank. (2020). The Economic and Social Impact of COVID-19, Western Balkans Regular Economic Report. World Bank Group. 